\title{
Konsep Keterbaruan Desain Alat Uji Berat Kereta Portabel
}

\author{
Wahyu Sulistiyo ${ }^{1, a}$, Mustasyar perkasa ${ }^{1,2, b}$, Yudi Irawadi ${ }^{1, \mathrm{c}}$, Barkah Fitriyana ${ }^{1, \mathrm{~d}}$, \\ dan Danardono Agus Sumarsono ${ }^{3, e}$
}

\author{
${ }^{1}$ Balai Besar Teknologi Kekuatan Struktur BPPT, Gd. 220 PUSPIPTEK, Tangerang Selatan, Indonesia \\ ${ }^{2}$ Program Studi Teknik Mesin, Universitas Pamulang, Jl. Surya Kencana No. 1, Tangerang Selatan, Indonesia \\ ${ }^{3}$ Departemen Teknik Mesin. Universitas Indonesia, Depok, Jawa Barat, Indonesia
}

E-mail: ${ }^{a}$ wahyu.sulistiyo@bppt.go.id; ${ }^{b}$ mustasyar.perkasa@bppt.go.id; cyudi.irawadi@bppt.go.id; dbarkah.fitriyana@bppt.go.id; ${ }^{\mathrm{D} D a n a r d o n @ e n g . u i . a c . i d ; ~}$

Masuk:18 September $2018 \quad$ Direvisi:1 September $2018 \quad$ Disetujui :27 Desember 2019

\begin{abstract}
Abstrak: Uji Berat pada kereta atau gerbong dilakukan dengan cara menghitung total berat Kereta dan menghitung distribusi berat pada masing-masing roda dengan cara menimbang beban yang diterima pada setiap roda. Tujuan dari penelitian ini adalah membuat konsep desain dan perhitungan kekuatan struktur alat uji berat kereta portabel yang dapat di gunakan untuk mengukur berat kereta di sepanjang jalan rel secara efisien dan akurat. Pengukuran berat kereta dilakukan untuk memastikan berat kereta terdistribusi secara merata pada tiap roda kereta dan memastikan agar muatan kereta tidak melebihi batas kemampuan kemampuan jalan rel. Faktor input dalam penelitian ini adalah load atau beban, ukuran meshing, jenis material dan model load cell dan dudukan load cell. Proses penelitian yang di lakukan berupa desain dan simulasi menggunakan finite elemen method terhadap load cell dan dudukan load cell. Faktor output dari penelitian ini adalah kekuatan struktur dari load cell dan kekuatan struktur dari dudukan load cell. Nilai tegangan ijin untuk baja ASTM A36 sebesar $160 \mathrm{MPa}$. Nilai tegangan ijin untuk baja SM 490 sebesar 230, dan nilai tegangan ijin untuk baja ASSAB 718 sebesar 574. Nilai tegangan maksimum material yang masih di bawah nilai tegangan ijinnya adalah material Assab 718. Sehingga material ini di pilih sebagai material load cell dan dudukan load cell.
\end{abstract}

Kata kunci: uji berat kereta, alat uji portable, load cell uji

Abstract: Weight test on the train or wagon is done by calculating the total weight of the train and calculating the weight distribution on each wheel by weighing the load received on each wheel. The purpose of this research is to design concepts and structure strength calculations for portable train weight test equipment that can be used to measure the weight of trains along the railroad efficiently and accurately. Train weight measurements are carried out to ensure that the weight of the train is evenly distributed on each train wheel and to ensure that the train load does not exceed the capability of the railroad. Input factors in this study are load or load, meshing size, material type and load cell model and load cell holder. The research process carried out in the form of design and simulation using the finite element method of the load cell and load cell holder. The output factors of this study are the structural strength of the load cell and the structural strength of the load cell holder. The permit stress value for ASTM A36 steel is $160 \mathrm{MPa}$. The permit stress value for SM 490 steel is 230, and the permit stress value for ASSAB 718 steel is 574. The maximum stress value of the material which is still below the permit stress value is Assab 718 material. So this material is selected as a load cell and load cell holder ..

Keywords: train weight test, portable test equipment, load cell test

\section{PENDAHULUAN}

Transportasi merupakan salah satu mata rantai jaringan distribusi barang dan mobilitas penumpang yang berkembang sangat dinamis, serta berperan di dalam mendukung, mendorong dan menunjang segala aspek kehidupan baik dalam pembangunan politik, ekonomi, sosial budaya dan pertahanan keamanan. Pertumbuhan sektor transportasi akan mencerminkan pertumbuhan ekonomi secara langsung sehingga transportasi mempunyai 
peranan yang penting dan strategis, baik secara makro maupun mikro. Dari aspek mikro, keberhasilan sektor transportasi diukur dari kapasitas yang tersedia, kualitas pelayanan, aksesibilitas, keterjangkauan daya beli masyarakat dan utilisasi. Salah satu transportasi yang menjadi andalan masyarakat pada saat ini adalah kereta api. Kereta api merupakan moda transportasi massal yang paling aman karena sejumlah karakteristik melekat dalam sistem perkeretaapian. Keselamatan transportasi saat ini sudah merupakan masalah global yang bukan sematamata masalah transportasi saja, tetapi sudah menjadi permasalahan sosial kemasyarakatan. Hal ini terlihat dari kepedulian WHO terhadap keselamatan dunia.

Pada era teknologi modern seperti sekarang, sistem peringatan dan perlindungan kereta api sangat dibutuhkan untuk mendukung standar keselamatan pada kereta api. Teknologi itu dirancang agar kecelakaan tak terjadi. Menurut peraturan menteri perhubungan no 13, 15, dan 17 tahun 2011 tentang Standar, Tata Cara Pengujian Dan Sertifikasi Kelaikan Kereta baik kereta dengan Penggerak Sendiri, kereta yang di tarik lokomotif, dan kereta barang atau gerbong, dalam pengoperasionalnya wajib memenuhi kelaikan operasi yang dibuktikan melalui pengujian. Uji Berat pada kereta atau gerbong dilakukan dengan cara menghitung total berat Kereta dan menghitung distribusi berat pada masing-masing roda dengan cara menimbang beban yang diterima pada setiap roda [1-3]. Tujuan dari penelitian ini adalah membuat konsep desain dan simulasi alat uji berat kereta portabel yang dapat di gunakan untuk mengukur berat kereta di sepanjang jalan rel secara real time dan akurat. Tujuan pengukuran berat kereta adalah untuk memastikan berat kereta terdistribusi secara merata pada tiap roda kereta dan memastikan agar muatan kereta tidak overload disesuaikan dengan kemampuan jalan rel.

\section{MATERIAL DAN METODE}

Gambar 1 menunjukkan sebuah rangkaian dari alat uji berat kereta portabel yang terpasang pada rel kereta. Alat ini terdiri dari beberapa komponen utama yaitu : Load cell, Dudukan load cell, penahan load cell. Material yang paling menjadi perhatian dalam penelitian ini adalah material load cell dan material dudukan load cell karena kedua komponen tersebut menerima beban langsung dari beban kereta. Material yang akan di kaji penggunaannya dalam penelitian ini adalah baja A36, SM 490 atau ASTM A572 Grade 50, ASSAB 718 atau ASTM A681 atau AISI P20

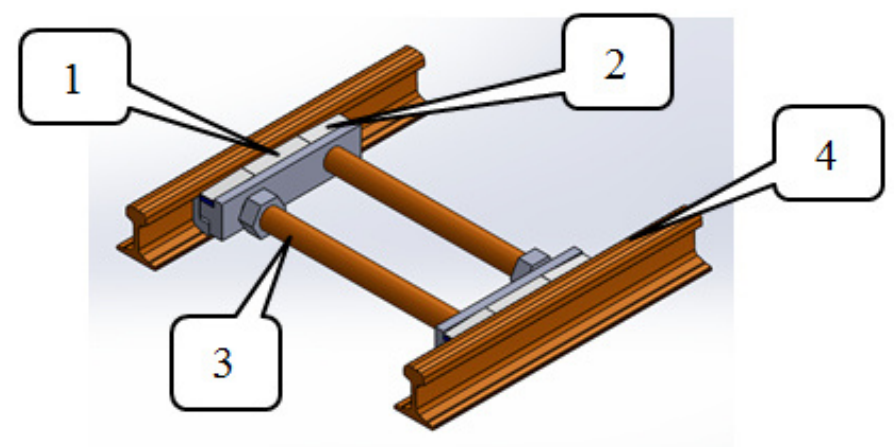

Gambar 1. Alat uji berat kereta portabel

Keterangan gambar

$1:$ Load cell

2 : dudukan load cell

3 : Penahan Load cell

4 : Rail

\section{Pemilihan material load cell dan dudukan load cell}

Material load cell dan dudukan load cell di buat sedemikian rupa agar mampu menerima beban kereta. Beban kereta terbesar ada pada lokomotif kereta yaitu sebesar 90 ton. Dengan jumlah load cell pada alat uji berat kereta sebanyak 2 buah dan jumlah roda kereta pada lokomotif sebanyak 12 buah maka satu load cell harus mampu menerima beban kurang lebih sebesar 10 ton. Material load cell dan dudukan load cell akan di buat dari beberapa alternatif material diantaranya baja A36, baja SM 490 dan baja Assab 718. Mechanical properties dari ketiga baja tersebut di tunjukkan pada Tabel 1. 
I Wahyu Sulistiyo dkk., Konsep Keterbaruan Desain Alat Uji Berat....,

Tabel 1. Mechanical properties material load cell dan dudukan load cell [4]

\begin{tabular}{ccccccc}
\hline Material & $\begin{array}{c}\mathbf{1} \\
\text { Ts MPa) }\end{array}$ & $\begin{array}{c}\mathbf{2} \\
\text { Ys (MPa) }\end{array}$ & $\begin{array}{c}\mathbf{3} \\
\mathbf{T}(\mathbf{M p a})\end{array}$ & $\begin{array}{c}\mathbf{4} \\
\mathbf{E ~ ( G P a )}\end{array}$ & $\begin{array}{c}\mathbf{5} \\
\mathbf{\rho}\left(\mathbf{k g} / \mathbf{m}^{\mathbf{3}}\right)\end{array}$ & $\begin{array}{c}\mathbf{6} \\
\mathbf{G P a})\end{array}$ \\
\hline $\begin{array}{c}\text { Baja A36 } \\
\text { Baja }\end{array}$ & 400 & 250 & 325 & 200 & 7850 & 79.3 \\
$\begin{array}{c}\text { A572/SM490 } \\
\text { Baja }\end{array}$ & 450 & 345 & 345 & 160 & 7800 & 80 \\
$\begin{array}{c}\text { A681/ASSAB } \\
\text { 718 }\end{array}$ & 1030 & 862 & 862 & 207 & 7861 & 210 \\
\hline
\end{tabular}

Tabel 1 menunjukkan bahwa mechanical properties untuk baja A681 mempunyai nilai yang paling unggul dari pada baja A572 grade 50 dan baja A36.

\section{Kekakuan material load cell dan dudukan load cell}

Defleksi maksimum dari material load cell di hitung dengan persamaan

$$
y=\frac{L l^{3}}{48 E I}
$$

y: Defleksi maksimum material $(\mathrm{mm})$; L: $\operatorname{Load}(\mathrm{N})$; 1: panjang material $(\mathrm{mm})$; E: Modulus elastisity $\left(\mathrm{N} / \mathrm{mm}^{2}\right)$; I: momen inertia penampang $\left(\mathrm{mm}^{4}\right)$.

\section{Perbandingan dan Ranking Material}

Membandingkan dan memeringkat material yang di gunakan bertujuan untuk menghitung kandidat material berdasarkan kriteria dan kebutuhan material yang akan digunakan [5]. Tahapan dalam melakukan perbandingan dan pemeringkatan material adalah sebagai berikut :

1. Menghitung nilai kebutuhan relatif dari property material $(\alpha)$

Tabel 2. Nilai kebutuhan material $(\alpha)$

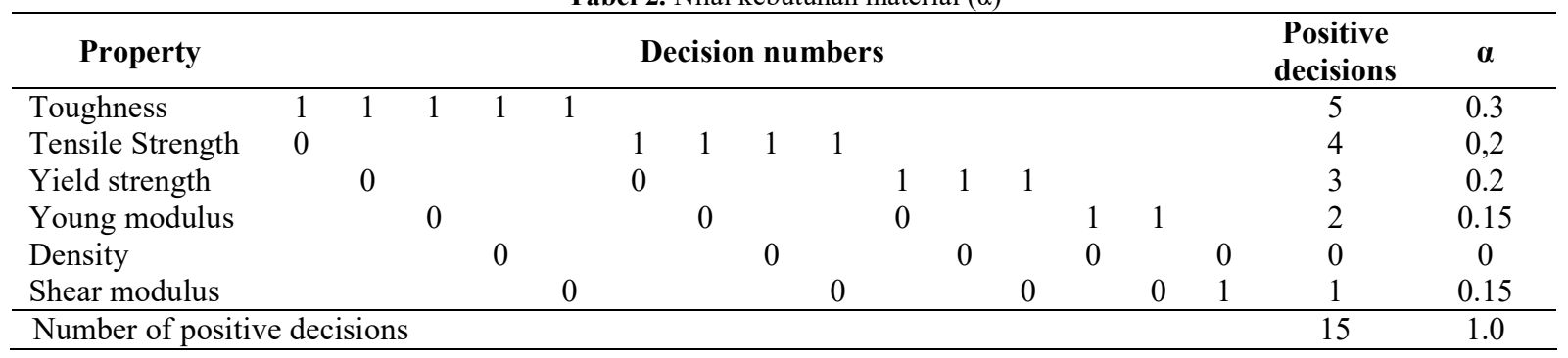

2. Menghitung nilai performance material $(\gamma)$ dengan persamaan

$$
\gamma=\sum_{i=1}^{n} \beta_{i} \alpha_{i}
$$

Tabel 3. Nilai performance $(\alpha)$

\begin{tabular}{cccccccc}
\hline Material & $\mathbf{1}$ & $\mathbf{2}$ & $\mathbf{3}$ & $\mathbf{4}$ & $\mathbf{5}$ & $\mathbf{6}$ & Performance value $(\gamma)$ \\
\hline Baja A36 & 38.8 & 29 & 37,7 & 96.6 & 99.8 & 37.7 & 45.13 \\
$\quad$ Baja & 43.6 & 40 & 40 & 77.2 & 99.2 & 38 & 46.36 \\
$\begin{array}{c}\text { A572/SM490 } \\
\text { Baja }\end{array}$ & & & & & & & 100 \\
$\begin{array}{c}\text { A681/ASSAB } \\
\text { 718 }\end{array}$ & 100 & 100 & 100 & 100 & 100 & 100 & \\
\hline
\end{tabular}

3. Menghitung nilai keberterimaan (Merit Value/M) dengan persamaan 


$$
\begin{aligned}
& \text { Cost }=\frac{C \rho}{S} \\
& M=\frac{\gamma}{C \rho}
\end{aligned}
$$

S: kekuatan tarik maksimum; C: biaya relatif; $\gamma$ : nilai performance; $\rho$ : berat jenis; M: nilai keberterimaan

Tabel 4. Merit value (M)

\begin{tabular}{cccccc}
\hline Material & $\begin{array}{c}\text { Relative } \\
\text { cost (C) }\end{array}$ & $\begin{array}{c}\text { Cost } \\
\text { per unit strength } \mathbf{~} \\
\mathbf{1 0 0}\end{array}$ & $\begin{array}{c}\text { Performance } \\
\text { value }(\gamma)\end{array}$ & Merit value (M) & Rank \\
\hline $\begin{array}{c}\text { Baja A36 } \\
\text { Baja }\end{array}$ & 1 & 1.96 & 45.13 & 23.02 & 3 \\
$\begin{array}{c}\text { A572/SM490 } \\
\text { Baja }\end{array}$ & 1 & 1.73 & 46.36 & 26.8 & 2 \\
$\begin{array}{c}\text { A681/ASSAB } \\
\text { 718 }\end{array}$ & 3 & 2.28 & & & 1 \\
\hline
\end{tabular}

Pada Tabel 4 menunjukkan nilai dari merit value atau nilai kepantasan untuk baja A681 mempunyai nilai paling tinggi di bandingkan dengan material baja A572 dan baja A36, sehingga baja A681 paling layak untuk di jadikan sebagai material loadcell pada alat uji berat kereta portabel. Tetapi sebagai bahan pertimbangan baja A36 dan Baja SM490 tetap akan dilakukan simulasi numerik sebagai pembuktian.

Alat uji berat kereta api terdiri dari load cell dan konstruksi pendukung. Desain awal dilakukan pada perancangan load cell. Perancangan load cell menyesuaikan dengan beberapa kondisi antara lain :

1. Load cell yang dirancang harus dapat menahan beban sebesar 10 Ton. Beban 10 Ton ini berasal dari beban per keping roda kereta api.

2. Nilai strain yang diinginkan untuk penentuan peletakkan strain gauge berada pada rentang nilai 900-1200 mikro strain.

3. Tegangan yang terjadi pada hasil simulasi pemodelan nantinya tidak melebihi nilai allowable stress material.

4. Bentuk load cell dirancang sesederhana mungkin, dengan pembuatan lubang untuk peletakkan strain gauge tidak mengganggu pemasangan strain gauge.

5. Bentuk load cell disesuaikan dengan rencana konstruksi pendukung dan jenis rel yang digunakan.

\section{Metodologi}

Metode penelitian yang di gunakan adalah design of experiment (Gambar 2). Dalam metode ini kita menentukan varian input, proses dan output sebagai point investigasi untuk proses experimen. Kolom input dalam metode ini berisi tentang variabel penelitian yang akan menghasilkan proses experimen. Pada kolom proses berisi tentang proses experimen yang di lakukan untuk menghasilkan hasil penelitian. Sedangkan pada kolom output berisi tentang hasil penelitian yang di harapkan untuk di capai.

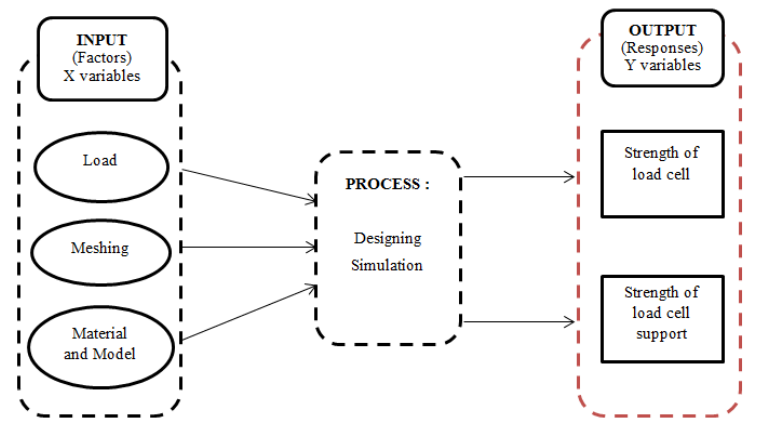

Gambar 2. Metode penelitian 
20 | Wahyu Sulistiyo dkk., Konsep Keterbaruan Desain Alat Uji Berat....,

Yang menjadi input faktor dalam penelitian ini adalah load atau beban, type meshing, material dan model dari load cell dan dudukan load cell. Proses penelitian yang di lakukan berupa desain dan simulasi dari bentuk load cell dan bentuk dudukan load cell. Output faktor dari penelitian ini adalah kekuatan struktur dari load cell dan kekuatan struktur dari dudukan load cell.

\section{HASIL DAN PEMBAHASAN}

\section{Kondisi Pembebanan}

Pembebanan pada alat uji berat kereta [1] berasal dari beban terbesar dari rangkaian kereta di kalikan dengan faktor dinamis karena beban bergerak [6]. Besarnya beban yang diterima oleh load cell dan dudukan load cell adalah :

$$
F_{Z}=\frac{[1.3 * M v * g]}{\text { jumlah roda kereta }}
$$

Dimana

$\mathrm{Fz}$

$\mathrm{Mv}$

$\mathrm{g}$

Jumlah roda kereta
: Gaya vertikal dari kereta $(\mathrm{N})$

: Massa lokomotif (90000 kg)

: Gravitasi $\left(9,81 \mathrm{~m} / \mathrm{s}^{2}\right)$

: 12 buah

Jadi besarnya gaya total per satu unit loadcell adalah 9,5 ton : $95647 \mathrm{~N}$

\section{Kondisi Batas}

Gambar 3 merupakan pemodelan load cell menggunakan software drawing solidworks. Pemodelan ini di buat berdasarkan investigasi dari bentuk dudukan load cell dan dimensi dari alat uji berat kereta portable. area A merupakan lokasi pembebanan di mana nantinya keping roda kereta api akan melewati area A. Area B yang berupa lubang merupakan lokasi untuk penempatan strain gauge [7]. Area ini di tentukan oleh hasil simulasi tegangan menggunakan software finite elemen method (FEM) [6, 8-11]. Area C sebagai fix support untuk load cell dalam arah sumbu x,y,z.

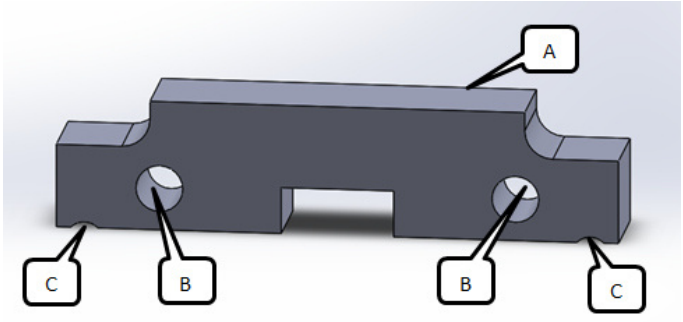

Gambar 3. Pemodelan Load cell

Load cell ini akan dilengkapi dengan konstruksi pendukung dengan desain sebagai berikut:

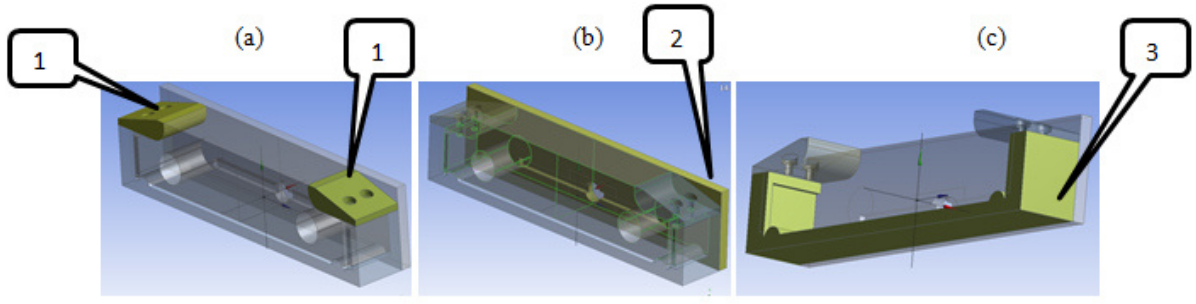

Gambar 4. (a) Konstruksi pendukung 1 (b) Konstruksi pendukung 2 (c) Konstruksi pendukung 3 


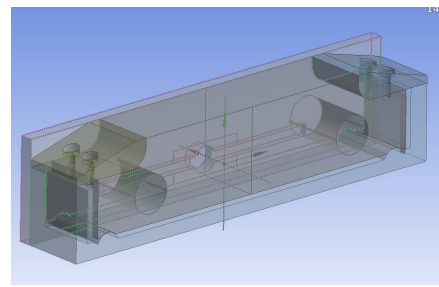

Gambar 5. Load cell assy

Sedangkan load cell dalam bentuk detail drawing sebagai berikut:

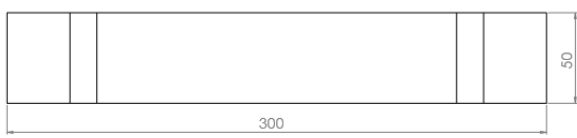

Gambar 6. Detail Drawing Load cell pada pandangan atas
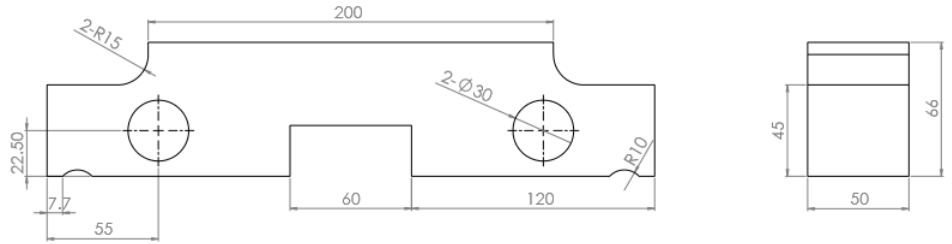

Gambar 7. Detail Drawing Load cell pada pandangan depan dan pandangan samping

\section{Modifikasi Pemodelan Alat Uji Berat Kereta}

Setelah melalui berbagai macam simulasi dan pertimbangan bentuk yang didiskusikan dengan calon pengguna maka di lakukan modifikasi bentuk load cell sebagai berikut

1. Pengurangan dimensi tinggi pada bagian atas load cell

2. Penambahan lubang baut pada bagian kiri dan kanan load cell cell

3. Menghilangkan lubang kotak yang ada di bawah load cell

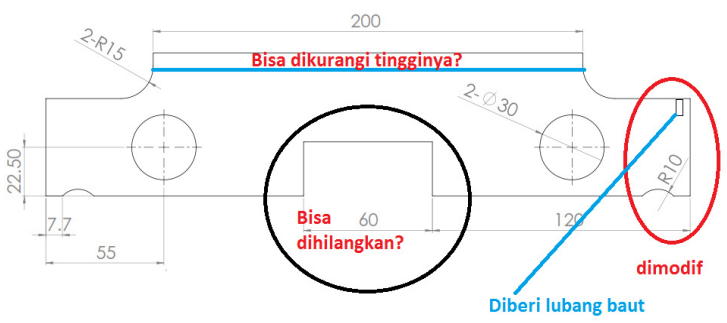

Gambar 8. Modifikasi bentuk load cell

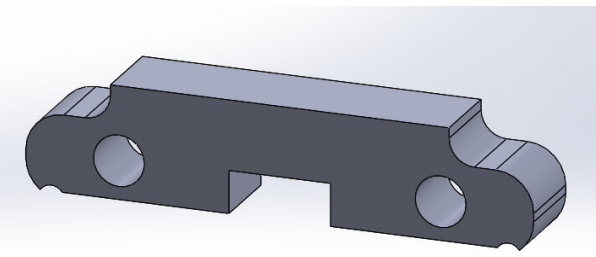

Gambar 9. Load cell hasil modifikasi 
22 | Wahyu Sulistiyo dkk., Konsep Keterbaruan Desain Alat Uji Berat....,

Modifikasi yang di lakukan setelah di lakukan evaluasi yaitu:

1. Pengurangan dimensi ketinggian pada poin 1 tidak dapat dilakukan karena desain sebelumnya telah mempertimbangkan ketinggian dengan dasar 2-3 mm digunakan untuk pelapisan logam tambahan guna memperkuat struktur load cell.

2. Penambahan lubang baut pada sisi kiri dan kanan load cell masing-masing sebanyak 2 buah dapat dilakukan karena tidak mengganggu struktur load cell.

3. Menghilangkan lubang kotak pada bagian bawah load cell tidak dapat dilakukan karena mengurangi sensitifitas pembacaan strain gauge pada load cell.

Selanjutnya, pemodelan load cell final setelah revisi akan diteruskan juga dengan simulasi tegangan dan regangan final dengan menggunakan bantuan software solidworks. Simulasi stress dan strain atau biasa juga dikenal dengan simulasi tegangan dan regangan pada load cell dilakukan untuk mengetahui nilai tegangan maksimum yang terjadi pada load cell dan membandingkan dengan kekuatan material yang dipakai, sehingga bisa ditarik kesimpulan apakah material yang dipakai aman digunakan dan mampu untuk menahan beban kerja yang diberikan.

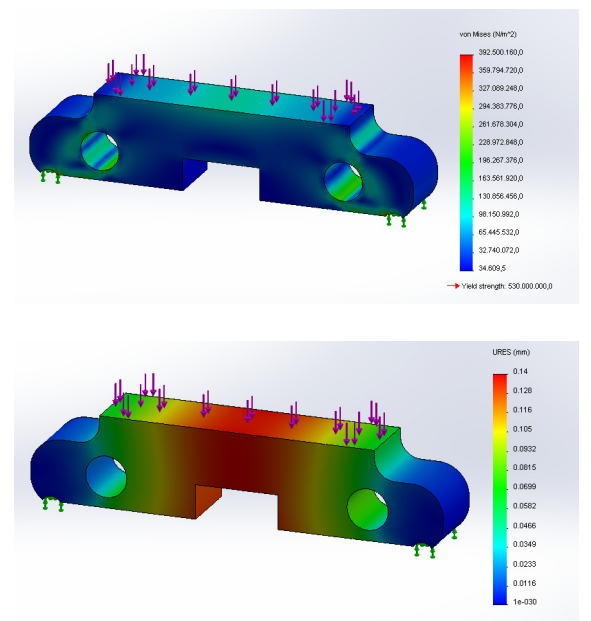

Gambar 9. Hasil simulasi tegangan dan hasil simulasi displacement load cell

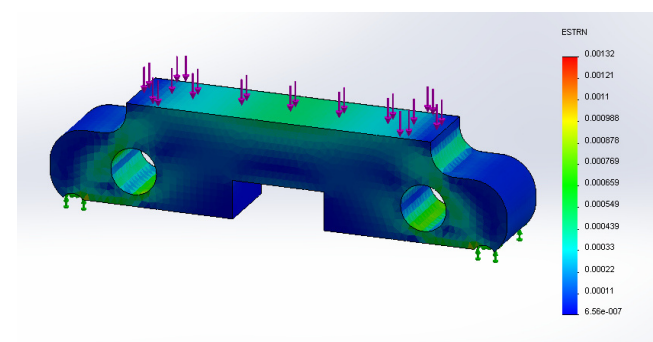

Gambar 10. Hasil simulasi regangan load cell

\section{Pembahasan}

Perhitungan defleksi maksimum pada material baja secara analitik sebagai berikut : Dead load untuk alat uji berat kereta per sisi sebesar $50 \mathrm{~kg}$. Live load is $90000 \mathrm{~kg}$. Factor of dynamic is 1.3 . Total load (L) is $1.3 \mathrm{x}(\mathrm{dead}$ load + live load $)=11000 \mathrm{~kg}$ atau $110000 \mathrm{~N}$. Jarak support (l) adalah $285 \mathrm{~mm}$. Moment inertia (I) adalah 1/12 $\mathrm{BH}^{3}$ $=3125000 \mathrm{~mm}^{4}$, modulus elastisitas (E) sebesar $200 \mathrm{Gpa}$. Sehingga defleksi maksimum dari load cell sebesar 0.1 $\mathrm{mm}$.

Dari hasil simulasi numerik di dapatkan nilai tegangan tertinggi sebesar $395 \mathrm{MPa}$. Dengan defleksi maksimum sebesar $1.43 \mathrm{~mm}$. Dan nilai strain tertinggi sebesar 13100 mikrostrain. Nilai tegangan ijin untuk baja ASTM A36 sebesar $160 \mathrm{MPa}$. Nilai tegangan ijin untuk baja SM 490 sebesar 230, dan nilai tegangan ijin untuk baja ASSAB 718 sebesar 574. Nilai tegangan yang masih di bawah nilai tegangan ijinnya hanya material Assab 718. Sehingga material ini di pilih sebagai material load cell dan dudukan load cell. Hasil simulasi numerik load cell dan dudukan load cell di tunjukkan pada Tabel 5. 
Tabel 5. Hasil simulasi numerik load cell

\begin{tabular}{|c|c|c|c|c|c|c|c|}
\hline Component & Material & Meshing & $\begin{array}{l}\text { No of } \\
\text { Node }\end{array}$ & $\begin{array}{c}\text { No of } \\
\text { Element }\end{array}$ & $\begin{array}{c}\text { Tegangan } \\
(\mathrm{MPa})\end{array}$ & $\begin{array}{c}\text { Result } \\
\text { Displacement } \\
(\mathrm{mm}) \\
\end{array}$ & $\begin{array}{c}\text { Regangan } \\
\text { (Microstrn) }\end{array}$ \\
\hline \multirow{9}{*}{$\begin{array}{l}\text { Load cell } \\
\text { dan } \\
\text { Dudukan } \\
\text { Load cell }\end{array}$} & \multirow{3}{*}{ A36 } & Coarse & 2590 & 1410 & 213 & 1.39 & 7120 \\
\hline & & Medium & 11939 & 7404 & 294 & 1,42 & 9350 \\
\hline & & Fine & 79244 & 53637 & 395 & 1.43 & 13100 \\
\hline & \multirow{3}{*}{ SM 490} & Coarse & 2590 & 1410 & 209 & 1.35 & 7010 \\
\hline & & Medium & 11939 & 7404 & 290 & 1.38 & 9230 \\
\hline & & Fine & 79244 & 53637 & 395 & 1.4 & 13000 \\
\hline & \multirow{3}{*}{$\begin{array}{c}\text { Assab } \\
718\end{array}$} & Coarse & 2590 & 1410 & 205 & 1.34 & 7080 \\
\hline & & Medium & 11939 & 7404 & 285 & 1.37 & 9340 \\
\hline & & Fine & 79244 & 53637 & 395 & 1.39 & 13100 \\
\hline
\end{tabular}

\section{KESIMPULAN}

Berdasarkan hasil analisis kekuatan material menggunakan finite elemen method (FEM) prosentase tegangan terendah terjadi pada material load cell dengan menggunakan assab 718 yaitu 13\% di bawah tegangan ijinnya. Tegangan maksimal pada semua material load cell sebesar $395 \mathrm{MPa}$. Tegangan ijin material A36 sebesar $160 \mathrm{MPa}$ maka hasil simulasi tegangan pada material A36 melebihi tegangan ijinnya. Tegangan ijin material SM 490 sebesar $250 \mathrm{MPa}$ maka hasil simulasi tegangan pada material SM 490 melebihi tegangan ijinnya. Pada material assab 718 tegangan ijinnya sebesar 473 Mpa sedangkan hasil simulasi tegangan di dapatkan tegangan maksimal sebesar $395 \mathrm{MPa}$ sehingga nilai tegangan material assab 718 masih berada di bawah tegangan ijin materialnya, sehingga material yang di pilih dalam pembuatan loadcell alat uji berat kereta adalah Assab 718 .

\section{DAFTAR PUSTAKA}

[1] Perhubungan, K., PM No 13, Standar, Tata Cara Pengujian dan Sertifikasi Kelaikan Kereta dengan Penggerak Sendiri. 2011

[2] Perhubungan, K., PM No 15, Standar, Tata Cara Pengujian Dan Sertifikasi Kelaikan Kereta Yang ditarik Lokomotif. 2011

[3] Perhubungan, K., PM No 17, Standar, Tata Cara Pengujian Dan Sertifikasi Kelaikan Gerbong. 2011

[4] ASME, <ASME Section II-D- Boiler and Pressure Vessel Code>. 2010

[5] Farag M M 2007 Materials and process selection for engineering design CRC Press.

[6] Railways I U o 1993 Passenger Rolling Stock, Bogie Frame Structure Strength Tests

[7] Žnidarič A et al 2016 Transportation Research Procedia 144010

[8] Khurmi R dan Gupta J K 1982 A Text Book Of Machine Design Eurasia Publishing House, Ram Nagar, New Delhi.

[9] Zakaria Y J U S B Analyzing a bogie frame behavior by using the experimental method and Ansys simulations 149

[10] Preumont A 2018 Vibration control of active structures an introduction Vol. 246 Springer.

[11] Juvinall R C 2007 Fundamentals of machine component design 